\title{
Humic substances may control dissolved iron distributions in the global ocean: Implications from numerical simulations
}

\author{
Kazuhiro Misumi, ${ }^{1}$ Keith Lindsay, ${ }^{2}$ J. Keith Moore, ${ }^{3}$ Scott C. Doney, ${ }^{4}$ \\ Daisuke Tsumune, ${ }^{1}$ and Yoshikatsu Yoshida ${ }^{1}$ \\ Received 11 November 2012; accepted 28 March 2013; published 20 May 2013.
}

[1] This study used an ocean general circulation model to simulate the marine iron cycle in an investigation of how simulated distributions of weak iron-binding ligands would be expected to control dissolved iron concentrations in the ocean, with a particular focus on deep ocean waters. The distribution of apparent oxygen utilization was used as a proxy for humic substances that have recently been hypothesized to account for the bulk of weak iron-binding ligands in seawater. Compared to simulations using a conventional approach with homogeneous ligand distributions, the simulations that incorporated spatially variable ligand concentrations exhibited substantial improvement in the simulation of global dissolved iron distributions as revealed by comparisons with available field data. The improved skill of the simulations resulted largely because the spatially variable ligand distributions led to a more reasonable basin-scale variation of the residence time of iron when present at high concentrations. The model results, in conjunction with evidence from recent field studies, suggest that humic substances play an important role in the iron cycle in the ocean.

Citation: Misumi, K., K. Lindsay, J. K. Moore, S. C. Doney, D. Tsumune, and Y. Yoshida (2013), Humic substances may control dissolved iron distributions in the global ocean: Implications from numerical simulations, Global Biogeochem. Cycles, 27, 450-462, doi:10.1002/gbc.20039.

\section{Introduction}

[2] It is now broadly accepted that organic ligands play a crucial role in determining dissolved iron concentrations in seawater. Electrochemical measurements have revealed that more than $99 \%$ of dissolved iron is complexed with organic ligands [Gledhill and van den Berg, 1994; Rue and Bruland, 1995; van den Berg, 1995]. Two iron-binding ligand classes are operationally defined: a strong ligand class $\mathrm{L}_{1}$ observed predominantly in surface waters and a weak ligand class $\mathrm{L}_{2}$ observed more ubiquitously throughout the whole water column [Rue and Bruland, 1995]. Whereas $\mathrm{L}_{1}$ ligands control iron availability for phytoplankton, $\mathrm{L}_{2}$ ligands strongly influence dissolved iron distributions below surface waters by regulating the residence time of dissolved iron [Hunter and Boyd, 2007; Misumi et al., 2011].

\footnotetext{
${ }^{1}$ Environmental Science Research Laboratory, Central Research Institute of Electric Power Industry, Abiko, Japan.

${ }^{2}$ Climate and Global Dynamics Division, National Center for Atmospheric Research, Boulder, Colorado, USA.

${ }^{3}$ Department of Earth System Science, University of California at Irvine, Irvine, California, USA.

${ }^{4}$ Department of Marine Chemistry and Geochemistry, Woods Hole Oceanographic Institution, Woods Hole, Massachusetts, USA.

Corresponding author: K. Misumi, Environmental Science Research Laboratory, Central Research Institute of Electric Power Industry, 1646 Abiko, Abiko, Chiba 270-1194, Japan. (misumi@criepi.denken.or.jp)

(C)2013. American Geophysical Union. All Rights Reserved. 0886-6236/13/10.1002/gbc.20039
}

[3] Although these ligands have not been fully identified chemically, previous field studies have suggested what their origin and fate may be. Possible sources of $\mathrm{L}_{1}$ ligands are siderophore production by marine microbes [Reid et al., 1993; Macrellis et al., 2001; Hunter and Boyd, 2007; Mawji et al., 2008; Ibisanmi et al., 2011], zooplankton grazing on phytoplankton [Sato et al., 2007], and viral cell lysis [Poorvin et al., 2011]; whereas $\mathrm{L}_{2}$ ligands are hypothesized to comprise a portion of the refractory dissolved organic carbon (DOC) pool produced during bacterial degradation of sinking particles [Hunter and Boyd, 2007; Laglera and van den Berg, 2009; Boyd et al., 2010; Boyd and Ellwood, 2010; Kondo et al., 2012].

[4] Iron complexation by ligands has been incorporated into most iron cycle/ocean general circulation coupled models (FeGCMs) [Moore et al., 2004; Parekh et al., 2005; Aumont and Bopp, 2006; Doney et al., 2006; Moore and Braucher, 2008]. The representation of ligands, however, is still rudimentary, and because knowledge regarding the geochemical cycle of ligands is limited, these models assume a single ligand class with a spatially homogeneous distribution. Application of the results of recent field studies to development of a better ligand parameterization for FeGCMs has therefore been a subject of great interest.

[5] Ye et al. [2009] have proposed an iron cycle model that includes fully prognostic ligand dynamics for both $\mathrm{L}_{1}$ and $\mathrm{L}_{2}$ ligand classes. The model assumes that phytoplankton produce $\mathrm{L}_{1}$ ligands under iron-limiting conditions, the rationale being that siderophores mediate iron acquisition and that $\mathrm{L}_{2}$ ligands result from the decomposition of detritus. 
The model considers photolysis and remineralization to be ligand sinks. Sensitivity experiments using a one-dimensional ocean model suggest that $\mathrm{L}_{2}$ ligands must have a long remineralization time scale and hence support the inference from field studies that $\mathrm{L}_{2}$ ligands are refractory DOC $[Y e$ et al., 2009]. However, because a one-dimensional approach cannot consider the importance of lateral advection on such a long timeframe, Ye et al. [2009] restored the $\mathrm{L}_{2}$ ligand concentrations to a typical $\mathrm{L}_{2}$ concentration in the deep Atlantic Ocean (2.5 nM) and did not discuss the details.

[6] More recently, Tagliabue and Völker [2011] have described an FeGCM that incorporates a diagnostic method to simulate both $\mathrm{L}_{1}$ and $\mathrm{L}_{2}$ ligands based on an empirical relationship between iron-binding ligands and DOC [Wagener et al., 2008a]. Total ligand concentrations are calculated as a function of total DOC, which is equated to the sum of simulated semi-labile DOC concentration and a spatially homogeneous refractory DOC concentration $(40 \mu \mathrm{M})$. Because refractory DOC accounts for most of the DOC in deep waters, the simulated deep-water $\mathrm{L}_{2}$ concentrations are almost homogeneous. The assumption that $\mathrm{L}_{2}$ ligands are proportional to total DOC may be inappropriate. Laglera and van den Berg [2009] found that humic substances, which amounted to only $4 \%$ of the total dissolved organic matter in their deep Pacific sample, accounted for the bulk of the iron-binding capacity, the implication being that $\mathrm{L}_{2}$ ligands should be parameterized as a function of the abundance of humic substances rather than total DOC. Because humic substances contribute to the humictype fluorescence (H-flu) intensity of chromophoric dissolved organic matter (CDOM) [Laglera and van den Berg, 2009], this suggestion is supported by many field observations that have shown significant correlations between iron solubility and the H-flu intensity of CDOM [Tani et al., 2003; Takata et al., 2005; Kitayama et al., 2009; Nishimura et al., 2012].

[7] Although the oceanic distribution of humic substances is still unclear, relatively well-established patterns in apparent oxygen utilization (AOU) can serve as good proxies for the distribution of $\mathrm{L}_{2}$ ligands. There is a linear relationship between the distributions of the H-flu intensity of CDOM and AOU over the Pacific Ocean basin [Yamashita and Tanoue, 2008]. Because three-dimensional, objectively analyzed AOU data are available on a global scale [Garcia et al., 2010], we can estimate the global distribution of $\mathrm{L}_{2}$ ligands by using that linear relationship. The apparent association between $\mathrm{L}_{2}$ ligands and AOU likely reflects the fact that particle remineralization controls both variables. Shipboard incubations have shown that release of $\mathrm{L}_{2}$ ligands accompanies remineralization of biogenic sinking particles [Boyd et al., 2010], which simultaneously consumes dissolved oxygen and increases AOU.

[8] The purpose of this study was to conduct a suite of FeGCM experiments to test the hypothesis that $\mathrm{L}_{2}$ ligands can be parameterized as a function of AOU. Use of the AOU-based formulation enables more skillful simulation of available dissolved iron concentrations, the implication being that humic substances, which are a small fraction of the refractory DOC pool, are a major component of $\mathrm{L}_{2}$ ligands and are playing an important role in the oceanic iron cycle.

\section{Model and Experimental Design}

[9] We used the biogeochemical elemental cycling (BEC) model [Moore et al., 2004; Moore and Braucher, 2008,
J. K. Moore et al., Marine ecosystem dynamics and biogeochemical cycling in the Community Earth System Model (CESM1.0), submitted to Journal of Climate] embedded in the Parallel Ocean Program version 2 (POP2) [Smith et al., 2010; Danabasoglu et al., 2012], which is the ocean component of the Community Earth System Model (CESM1; available online at http://www.cesm.ucar.edu). We used a course resolution configuration [Shields et al., 2012] with a nominal $3^{\circ}$ irregular horizontal grid [Yeager et al., 2006] and 60 vertical layers [Yeager and Jochum, 2009] to conduct a number of long-term sensitivity experiments. Coupled to the model was a sea ice component, the Community Ice CodE version 4 (CICE4) [Hunke and Lipscomb, 2008; Holland et al., 2012], with the same horizontal mesh as the POP2. The atmospheric and terrestrial components were turned off, because interaction with these components was beyond the scope of this study. The ocean and sea ice components were driven by a synthetic, cyclical "normal year" forcing [Large and Yeager, 2004]: $6 \mathrm{~h}$ average atmospheric state data based on the National Centers for Environmental Prediction reanalysis [Kalnay et al., 1996], daily satellite radiation data [Zhang et al., 2004], and monthly precipitation from Xie and Arkin [1996] and the Global Precipitation Climatology Project [Huffman et al., 1997].

[10] The BEC model includes four classes of phytoplankton functional types: pico/nanoplankton, coccolithophores, diatoms, and diazotrophs; one class of zooplankton; five nutrients: dissolved nitrate, ammonium, phosphorus, iron, and silicate; inorganic carbon system geochemistry; and oxygen cycling. The simulated ecology and biogeochemistry, including the iron cycle, are well documented in previous studies [Moore et al., 2004; Moore and Braucher, 2008; Doney et al., 2009a; Doney et al., 2009b; Misumi et al., 2011; Moore et al., submitted manuscript].

[11] The model considers two external iron sources: aeolian dust [Luo et al., 2003] and seafloor sediments [Moore and Braucher, 2008]. Aeolian dust is assumed to contain a constant fraction of iron (3.5 wt.\%), and $1 \%$ of the iron in the dust dissolves instantaneously at the sea surface. The model also considers dissolution of dust-associated iron during sinking in the water column [Moore and Braucher, 2008]. Dissolved iron is utilized for phytoplankton growth and is subject to particle scavenging.

[12] The current BEC model considers a single iron-binding ligand class without explicit representation of the chemical equilibrium between iron and the binding ligand [Moore and Braucher, 2008]. However, the simulated iron-scavenging rates are similar to those calculated by a model that explicitly represents a chemical equilibrium with a conditional stability constant for $\mathrm{L}_{2}$ ligands $\left(\log _{10} K_{\mathrm{Fe}^{\prime} \mathrm{L} 2} \sim 11-12\right.$; where $K_{\mathrm{Fe}^{\prime} \mathrm{L} 2}=\left[\mathrm{FeL}_{2}\right] /\left[\mathrm{Fe}^{\prime}\right]\left[\mathrm{L}_{2}^{\prime}\right], \mathrm{Fe}^{\prime}$ is free iron, $\mathrm{L}_{2}^{\prime}$ is free $\mathrm{L}_{2}$ ligand, and $\mathrm{FeL}_{2}$ is iron bound by $\mathrm{L}_{2}$ ligands) [see Misumi et al., 2011, appendix]. The BEC model is therefore applicable to investigating the distribution of $\mathrm{L}_{2}$ ligands. We acknowledge, however, that the current $\mathrm{BEC}$ model does not represent competitive reactions of $\mathrm{L}_{1}$ and $\mathrm{L}_{2}$ ligands with dissolved iron, which may be important in the upper ocean.

[13] We assumed a linear relationship between $\mathrm{L}_{2}$ ligands and AOU because $\mathrm{L}_{2}$ ligands are suggested to be composed primarily of humic substances [Laglera and van den Berg, 

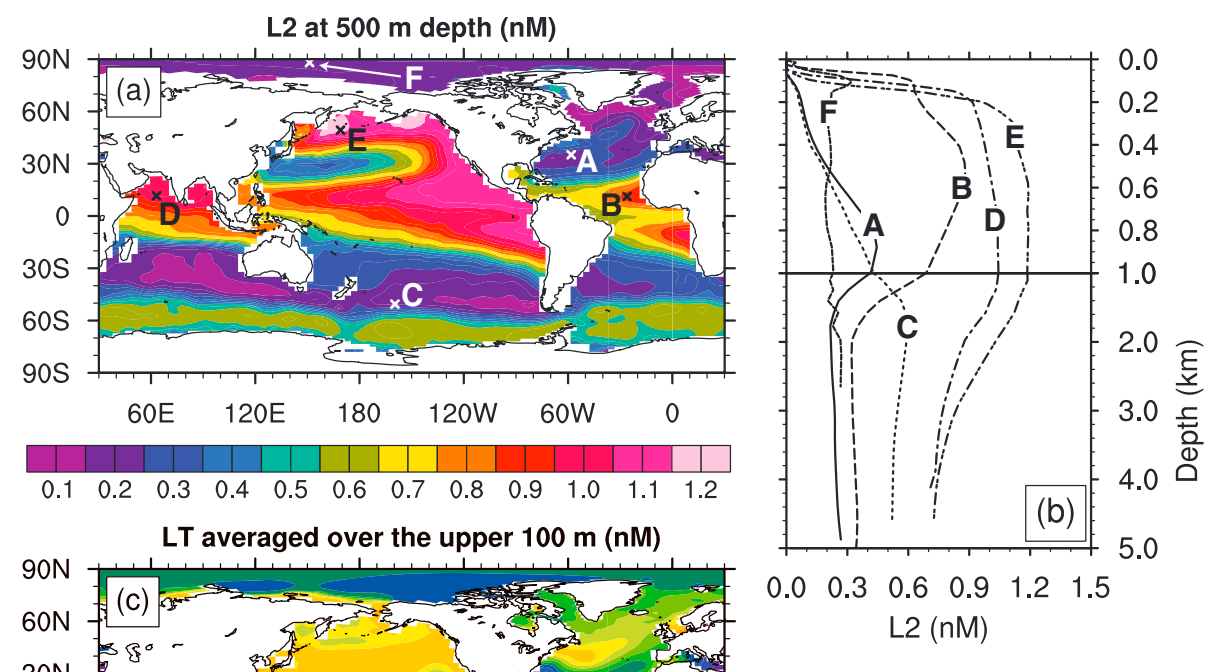

Figure 1. (a) A spatial map of $\mathrm{L}_{2}$ ligand concentrations (nM) at a depth of $500 \mathrm{~m}$ used for the AOU_06 case. (b) Vertical profiles of the $\mathrm{L}_{2}$ ligand concentrations at selected locations: in the subtropical North Atlantic Ocean "A," in the equatorial Atlantic Ocean "B," in the Southern Ocean "C," in the Arabian Sea "D," in the subarctic North Pacific Ocean "E," and in the Arctic Ocean "F.". (c) Surface total ligand concentrations $\left(L_{\mathrm{T}}=L_{1}+L_{2}\right)$ averaged over the upper $100 \mathrm{~m}$ used in the AOU_DOC case.

2009], the concentrations of which are proportional to AOU [Yamashita and Tanoue, 2008]:

$$
L_{2}=\alpha A O U+\beta,
$$

where $L_{2}$ and $A O U$ are $\mathrm{L}_{2}$ ligands and AOU, respectively, and $\alpha$ and $\beta$ are the rate of $\mathrm{L}_{2}$ ligand production per unit oxygen consumption and a background $\mathrm{L}_{2}$ ligand concentration, respectively.

[14] Because there are no literature values for $\alpha$ and $\beta$, we transformed equation (1) by expressing the background $\mathrm{L}_{2}$ ligand concentration $\beta$ as a fraction of the global spatial average $\mathrm{L}_{2}$ ligand concentration, $<L_{2}>$ :

$$
\beta=f\left\langle L_{2}\right\rangle,
$$

where $f$ represents the fraction and the angle brackets represent the global spatial average. Substituting equation (2) into equation (1), taking the global spatial average of both sides, and solving for $\alpha$ give

$$
\alpha=(1-f) \frac{\left\langle L_{2}\right\rangle}{\langle A O U\rangle} .
$$

[15] Thus equation (1) can be rewritten as

$$
L_{2}=(1-f) \frac{\left\langle L_{2}\right\rangle}{\langle A O U\rangle} A O U+f\left\langle L_{2}\right\rangle .
$$

[16] The equation for $\mathrm{L}_{2}$ thus involves two new parameters, $\left\langle L_{2}>\right.$ and $f$. The parameter $f$ can be interpreted as the importance of the background term (the second term on the right-hand side (RHS)) relative to the AOU-dependent term (the first term on the RHS) in equation (2).

[17] In this study, we adopted an objectively analyzed, databased AOU [World Ocean Atlas, 2009; Garcia et al., 2010] to calculate $\mathrm{L}_{2}$ ligand concentrations rather than the simulated AOU because of the known AOU bias in the model (Moore et al., submitted manuscript). Figures $1 \mathrm{a}$ and $1 \mathrm{~b}$ illustrate the $\mathrm{L}_{2}$ ligand distribution for $\left\langle L_{2}\right\rangle=0.6 \mathrm{nM}$ and $f=0.0$. In this case, the $\mathrm{L}_{2}$ concentrations are determined solely by the AOU term; the concentrations are generally lower in the Atlantic, Southern, and Arctic Oceans (Figure 1b; locations $\mathrm{A}, \mathrm{C}$, and F) and higher in equatorial regions and in the Indian and Pacific oceans (Figure 1b; locations B, D, and E), a pattern consistent with the distribution of AOU. At a depth of $500 \mathrm{~m}$ (Figure 1a), there is an influence from wind-driven circulation: $\mathrm{L}_{2}$ concentrations on depth surfaces in the thermocline are higher and lower because of Ekman upwelling and downwelling, respectively.

[18] We conducted three series of experiments designated CONST, AOU, and AOU- $f$ (Table 1). In the CONST series, we fixed $f$ at 1.0 and let $\left\langle L_{2}>\right.$ range from 0.0 to $1.2 \mathrm{nM}$. Fixing $f$ at 1.0 eliminated the first term on the RHS of equation (4), the result being a series of spatially homogeneous $\mathrm{L}_{2}$ concentrations. The CONST_06 and CONST_12 cases (Table 1) corresponded to the standard experiments in Moore and Braucher [2008] and Misumi et al. [2011], respectively. In contrast, we set $f$ equal to 0.0 in the AOU series, thereby eliminating the second term on the RHS of equation (4), the result being that $\mathrm{L}_{2}$ ligand concentrations 
Table 1. Experimental Cases ${ }^{\mathrm{a}}$

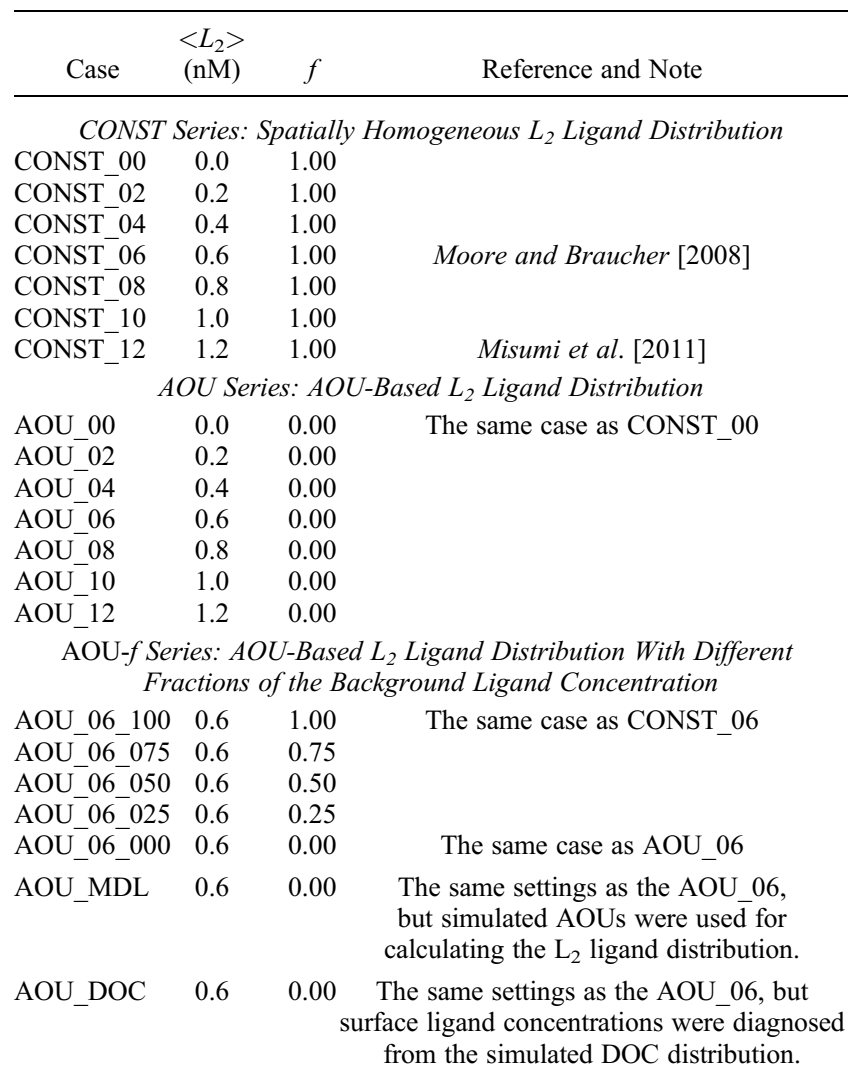

\footnotetext{
${ }^{\text {a }}$ The parameters $\left\langle L_{2}>\right.$ and $f$ represent the global spatial average $\mathrm{L}_{2}$ ligand concentration and the ratio of the background $\mathrm{L}_{2}$ ligand concentration to $<L_{2}>$, respectively. In all cases involving AOU-based $\mathrm{L}_{2}$ ligands other than AOU MDL, an objectively analyzed AOU [World Ocean Atlas, 2009; Garcia et al., 2010] was used for calculating the concentrations of $\mathrm{L}_{2}$ ligands. In the AOU MDL case, the simulated AOU was used for the calculation.
}

were directly proportional to AOU; i.e., the background concentration was zero. In the AOU- $f$ series, we fixed $\left\langle L_{2}>\right.$ at $0.6 \mathrm{nM}$, a best estimate from the CONST and AOU series, and varied the value of $f$ from 0.0 to 1.0 . Note that the AOU_06_100 and AOU_06_000 cases (Table 1) are the same as the CONST_06 and AOU_06 cases, respectively.

[19] We conducted two additional experiments designated AOU_MDL and AOU_DOC. In these cases, $<L_{2}>$ and $f$ were fixed at $0.6 \mathrm{nM}$ and $0 . \overline{0}$, respectively, the best values among the CONST, AOU, and AOU-f series. In the AOU_MDL case, we calculated $\mathrm{L}_{2}$ ligand concentrations from simulated AOU. This experiment was intended to evaluate the influence of the bias in the simulated AOU on the simulated dissolved iron concentrations. It is also noteworthy that use of the simulated AOU created a feedback between iron and binding ligand concentrations: iron concentrations constrain primary production and hence export production, which in turn modulates AOU and thus the simulated ligand concentrations.

[20] In the AOU_DOC case, we tested a combination of our formulation with the DOC-based formulation of Tagliabue and Völker [2011]. They calculated total ligand concentrations, $L_{\mathrm{T}}$ in $\mathrm{nM}$, with the equation

$$
L_{\mathrm{T}}=L_{1}+L_{2}=\left(D O C_{\mathrm{TOT}} \times 0.09\right)-3.2,
$$

where $D O C_{\text {TOT }}$ represents the sum of semi-labile DOC $\left(D O C_{\mathrm{semi}}\right)$ and refractory DOC $\left(D O C_{\mathrm{ref}}\right)$ in $\mu \mathrm{M}$; the factor
0.09 and the offset 3.2 are in units of $n M(\mu M)^{-1}$ and $n M$, respectively. They used a simulated $D O C_{\text {semi }}$ concentration and assumed a homogeneous $D O C_{\text {ref }}$ concentration of 40 $\mu \mathrm{M}$ to calculate $L_{\mathrm{T}}$ from equation (5). They apportioned two thirds of the ligands associated with $D O C_{\text {semi }}$ to $L_{1}$ and the remaining one third to $L_{2}$; all $L_{\mathrm{T}}$ associated with $D O C_{\text {ref }}$ was apportioned to $L_{2}$, and an adjustment was made to account for the background $L_{2}$ concentration:

$$
\begin{gathered}
L_{1}=\frac{2}{3} D O C_{\text {semi }} \times 0.09, \\
L_{2}=\left(\frac{1}{3} D O C_{\text {semi }}+D O C_{\text {ref }}\right) \times 0.09-3.2 .
\end{gathered}
$$

[21] Because semi-labile DOC is not found in deep waters, the simulated deepwater $\mathrm{L}_{2}$ concentration is spatially homogeneous $(0.4 \mathrm{nM})$. In the AOU DOC case, we tested a combination of equations (4) and ( $\overline{6}$ ). Because our model has only a single ligand class, we equated the ligand concentration to the sum of $\mathrm{L}_{1}$ and $\mathrm{L}_{2}$ calculated from equations (4) and (6), respectively. The surface ligand concentrations so calculated in the AOU_DOC case were generally lower than those in Tagliabue and Völker [2011] (Figure 1c), the difference being due mainly to the lower surface $\mathrm{L}_{2}$ concentrations calculated with our method. We acknowledge that the AOU_DOC case ignores competitive reactions involving the two ligand classes with dissolved iron and underestimates the binding strength of $\mathrm{L}_{1}$ ligands. This experiment was intended only to evaluate the first-order impact of using a best possible combination of $\mathrm{L}_{1}$ and $\mathrm{L}_{2}$ for the ligand distribution.

[22] The initial conditions for the model simulations were based on field data: temperatures and salinities were taken from the Polar Science Center Hydrographic Climatology

\begin{tabular}{|c|c|c|c|}
\hline & ALL & ALL-COAST & ALL-COAST-OUT \\
\hline$N_{\text {surf }}$ & 8238 & 3864 & 3692 \\
\hline \multicolumn{4}{|l|}{$R_{\text {surf }}^{2}$} \\
\hline CONST 06 & 0.11 & 0.15 & 0.32 \\
\hline AOU_ $0 \overline{6}$ & 0.11 & 0.16 & 0.35 \\
\hline \multicolumn{4}{|l|}{$\operatorname{RMSE}_{\text {surf }}(\mathrm{nM})$} \\
\hline CONST_06 & 0.85 & 0.69 & 0.57 \\
\hline AOU_0 $0 \overline{6}$ & 0.78 & 0.61 & 0.46 \\
\hline$N_{\text {deep }}$ & 3788 & 1853 & 1325 \\
\hline \multicolumn{4}{|l|}{$R_{\text {deep }}^{2}$} \\
\hline CONST 06 & 0.02 & 0.30 & 0.46 \\
\hline AOU $0 \overline{6}$ & 0.04 & 0.39 & 0.61 \\
\hline \multicolumn{4}{|l|}{$\operatorname{RMSE}_{\text {deep }}(\mathrm{nM})$} \\
\hline CONST_06 & 0.89 & 0.36 & 0.27 \\
\hline AOU $0 \overline{6}$ & 0.86 & 0.33 & 0.23 \\
\hline
\end{tabular}

Table 2. Skill Scores Comparing the Simulated Results With Field Data ${ }^{\mathrm{a}}$

a" $N$," " $R$," and "RMSE" are the number of data, the coefficients of determination, and the root mean square errors, respectively. Subscripts "surf" and "deep" represent $N, R_{,}^{2}$ and RMSE for the surface $(0-200 \mathrm{~m})$ and deep (200-5000 m) waters, respectively. Each column of the table compares the simulated results with different subsets of the field data: "ALL" represents all the data compiled by Tagliabue et al. [2012]; "ALL-COAST" represents the same data as "ALL" but excluding data near the coast (within $500 \mathrm{~km}$ ); "ALL-COAST-OUT" represents the same data as "ALL-COAST" but excluding outliers (see text). The subset of "ALL-COAST-OUT" was used for comparison with the simulated results. The simulated data were subsampled from the same month, location, and depth as the field data. 


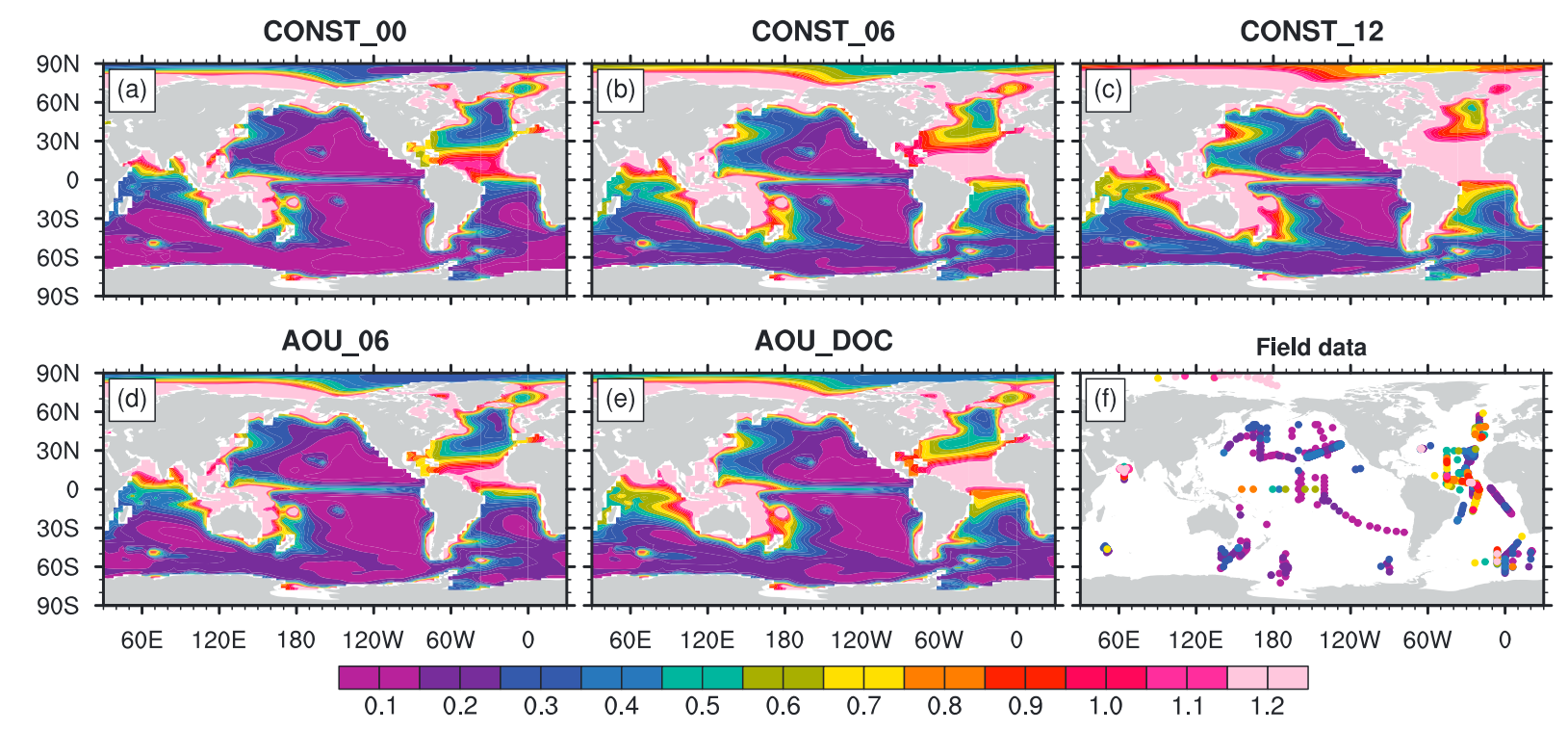

Figure 2. Simulated dissolved iron concentrations (nM) averaged over the upper $200 \mathrm{~m}$ for the (a) CONST_00, (b) CONST_06, (c) CONST_12, (d) AOU_06, and (e) AOU_DOC cases. (f) Observed dissolved iron concentrations (compiled by Tagliabue et $\overline{\text { all. }}$. [2012] averaged over the upper $200 \mathrm{~m}$ and excluding subsets (see text).

2 [Steele et al., 2001]; macronutrients from the World Ocean Atlas 98 [Conkright et al., 1998]; and preindustrial dissolved inorganic carbon and alkalinity from the Global Data Analysis Project [Key et al., 2004]. Dissolved iron concentrations were taken from a long-term BEC model simulation. The atmospheric $\mathrm{CO}_{2}$ concentration was fixed at the preindustrial value ( $289 \mathrm{ppm})$. The model was first spun-up for 150 years in the CONST 06 configuration; from the end of the spin-up calculation, the model was then further integrated for 150 years in the individual case (Table 1) configurations.
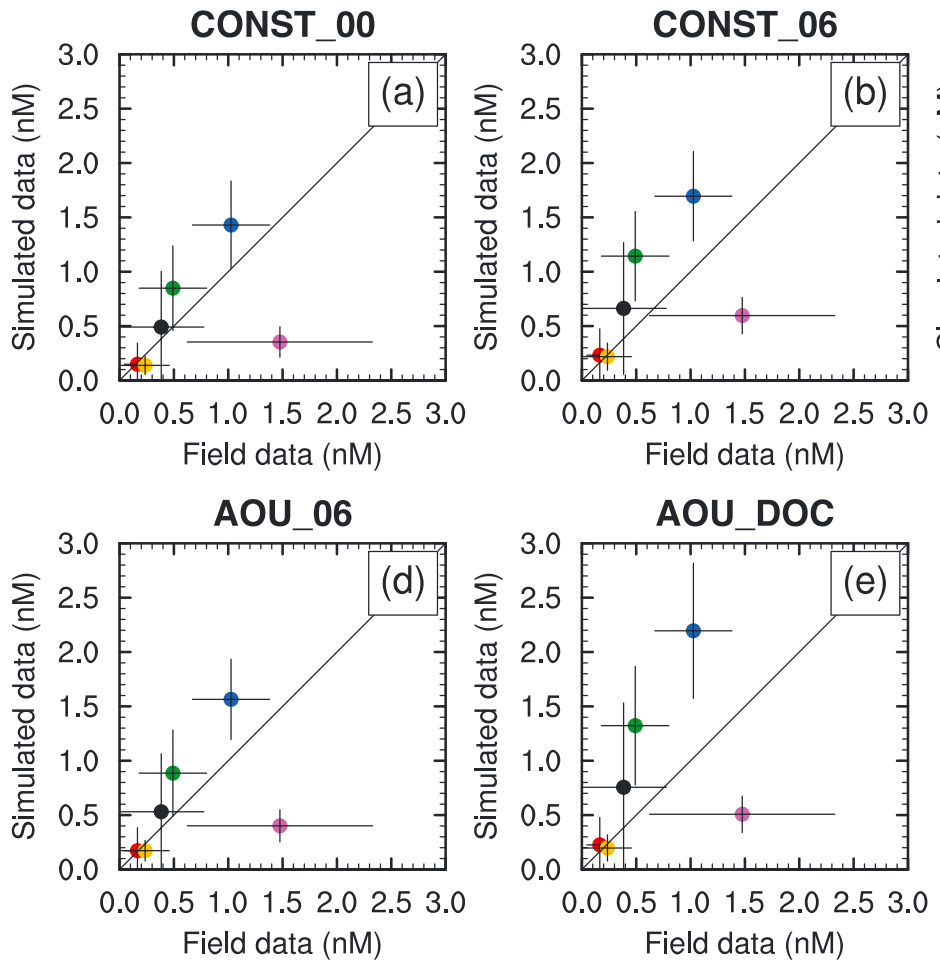

AOU_DOC

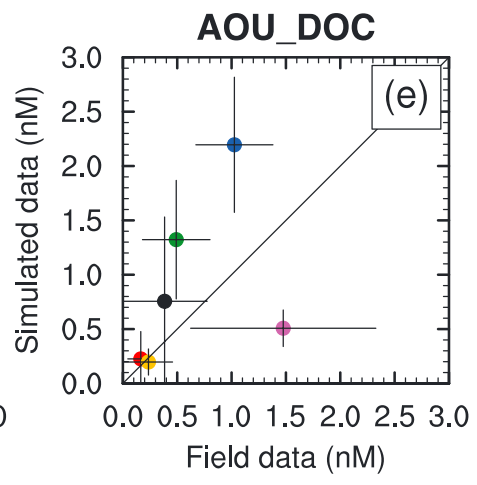

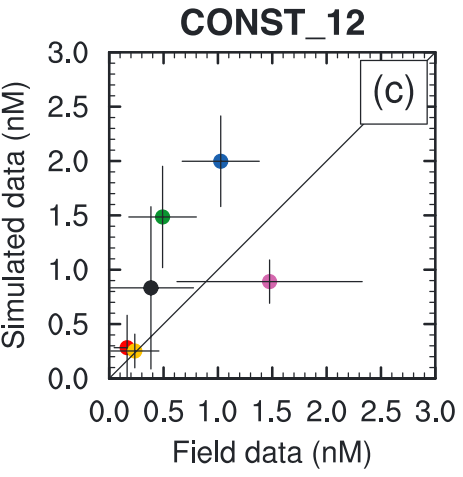

- Global

- Pacific Ocean Southern Ocean

- Atlantic Ocean

- Indian Ocean

- Arctic Ocean

Figure 3. Scatterplots comparing the observed (horizontal axes) and the simulated (vertical axes) dissolved iron concentrations averaged over the upper $200 \mathrm{~m}$ of each ocean (black: Global; red: Pacific Ocean; yellow: Southern Ocean; green: Atlantic Ocean; blue: Indian Ocean; and purple: Arctic Ocean) for the (a) CONST_00, (b) CONST_06, (c) CONST_12, (d) AOU_MDL, and (e) AOU_DOC cases. The horizontal and vertical bars represent the standard deviations for each ocean. 

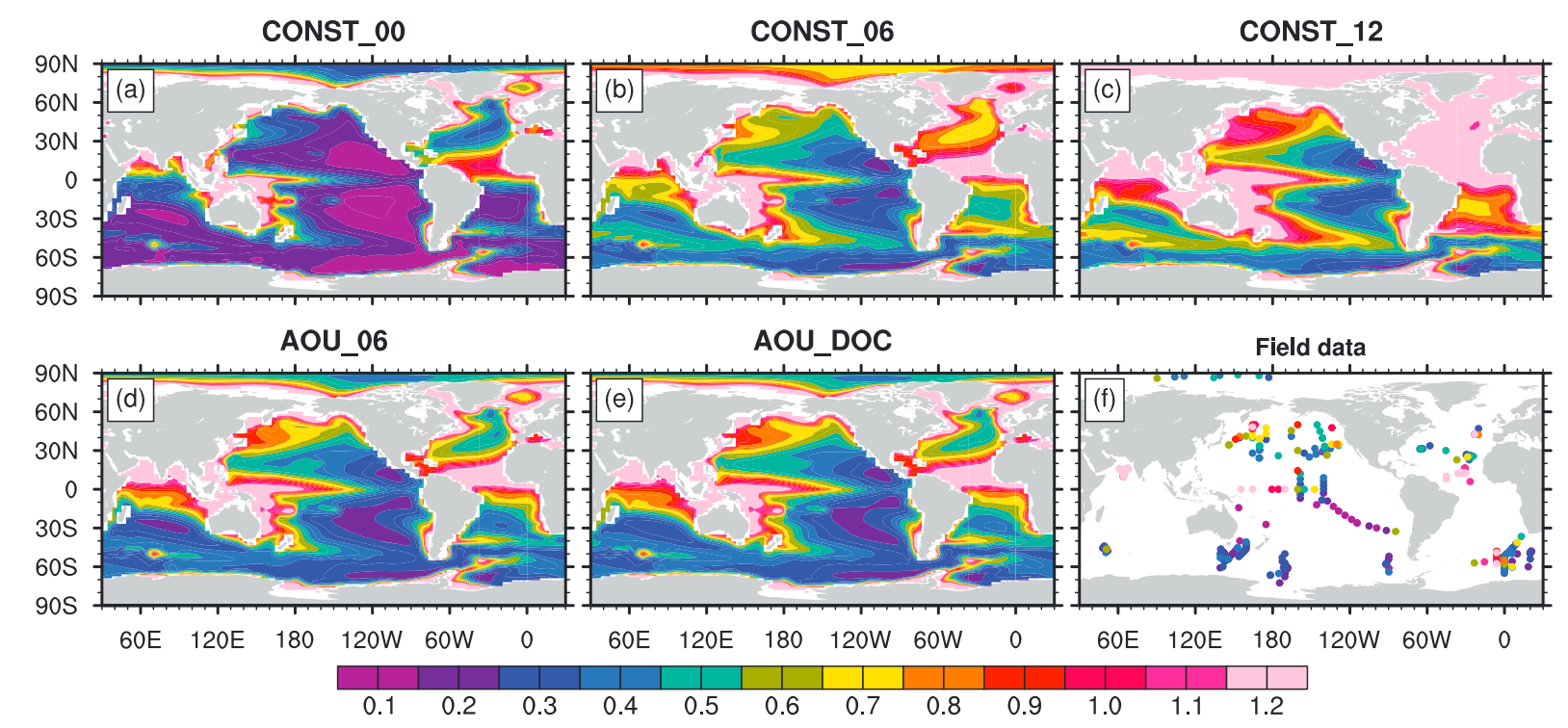

Figure 4. Simulated dissolved iron concentrations (nM) averaged over depths of $200-1000 \mathrm{~m}$ for the (a) CONST_00, (b) CONST_06, (c) CONST_12, (d) AOU_06, and (e) AOU_DOC cases. (f) Observed dissolved iron concentrations (compiled by Tagliabue et al. [2012] averaged over depths of 200-1000 $\mathrm{m}$ but excluding subsets (see text).

The simulated dissolved iron concentrations changed significantly from the spin-up simulation, and 150 years are long enough for coming into new quasi steady state. The simulated dissolved iron concentrations exhibited reasonably small temporal trends both in surface and deep waters (i.e., the absolute values of the linear regression coefficients for the global mean dissolved iron concentrations for the last
10 years at surface and $3000 \mathrm{~m}$ depth were less than $0.0001 \mathrm{nM} \mathrm{yr}^{-1}$ in all cases). Here we discuss the results from the last year of the simulation.

[23] We compared the simulated dissolved iron concentrations with field data compiled by Tagliabue et al. [2012], thereby roughly doubling the total number of data compiled by Moore and Braucher [2008]. We excluded two subsets of
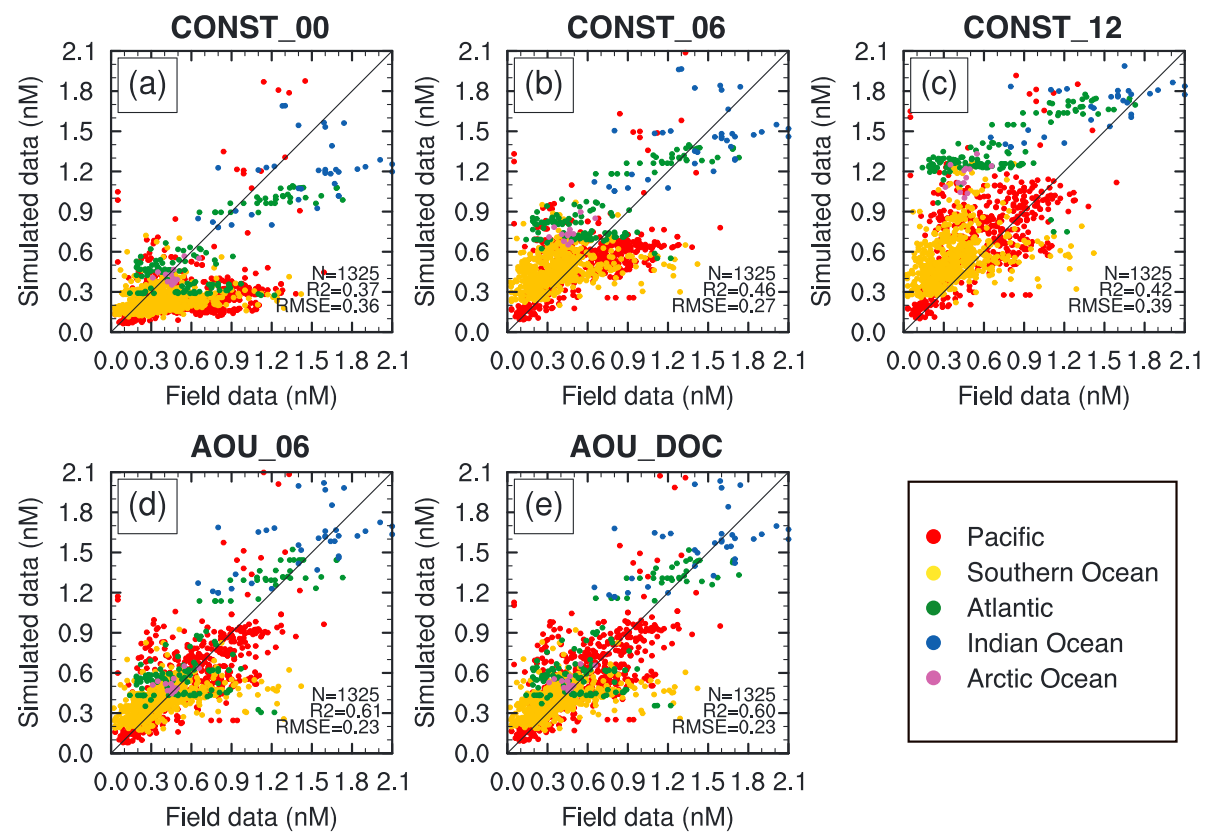

Figure 5. Scatterplots comparing the observed (horizontal axes) and simulated (vertical axes) dissolved iron concentrations in the depth interval 200-5000 m of each ocean (red: Pacific Ocean; yellow: Southern Ocean; green: Atlantic Ocean; blue: Indian Ocean; and purple: Arctic Ocean) for the (a) CONST_00, (b) CONST 06, (c) CONST 12, (d) AOU MDL, and (e) AOU_DOC cases. "N," "R2," and "RMSE" in the panels are the number of data, the coefficient of determination, and the root mean square error, respectively. 

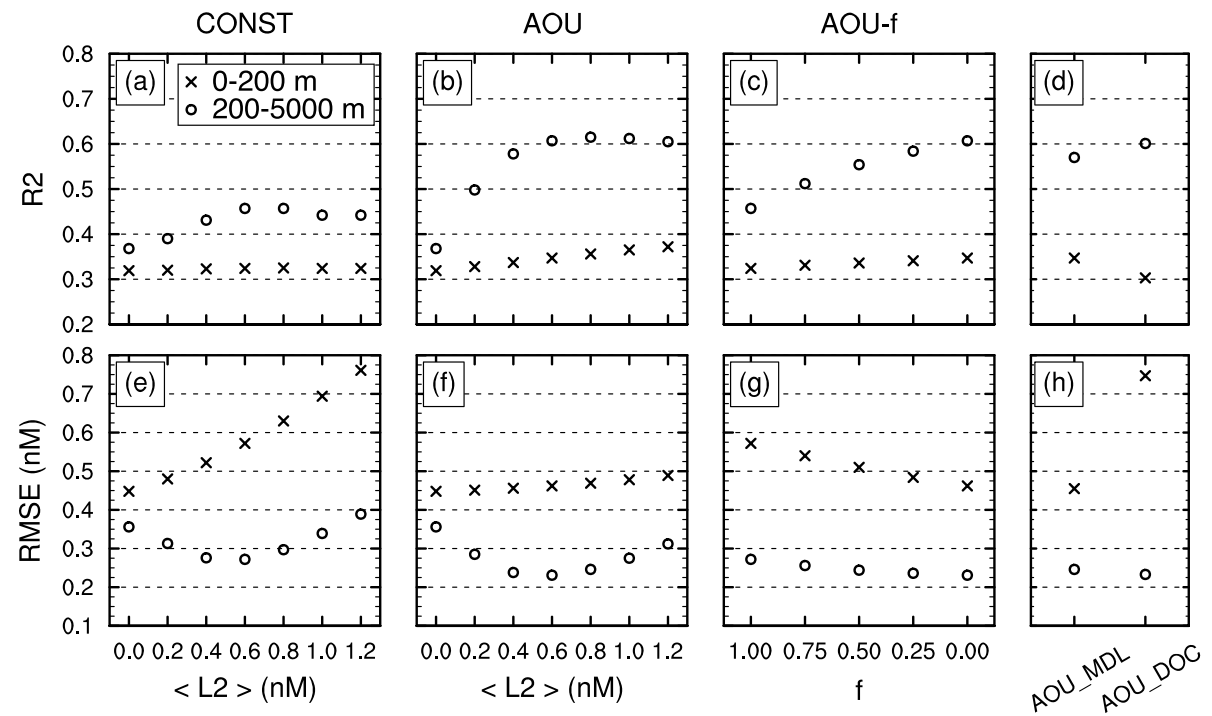

Figure 6. Sensitivity of (a-d) $R^{2}$ and $(\mathrm{e}-\mathrm{h}) \mathrm{RMSE}(\mathrm{nM})$ to the parameters: $\left\langle L_{2}\right\rangle(\mathrm{nM})$ for the CONST and AOU series; $f$ for the AOU- $f$ series. The sensitivity to the different ligand formulations. Crosses and circles represent the results for the surface water $(0-200 \mathrm{~m})$ and the deep water $(200-5000 \mathrm{~m})$, respectively.

field data from the comparison. Data within $500 \mathrm{~km}$ of the coast (referred to as the "COAST" subset) were excluded because the coarse global model does not do a good job resolving the finer-scale patterns and processes in coastal systems. Also excluded were outliers (referred to as the "OUT" subset), which were defined as data exceeding a threshold of

$$
\left|x_{i}-m_{i}\right|>2 \sigma_{i} \text {. }
$$

where $x_{i}$ is an individual field datum, and $m_{i}$ and $\sigma_{i}$ are averages and standard deviations for data within a water column having its center at the location of $x_{i}$, a radius of $3000 \mathrm{~km}$, and a thickness of $200 \mathrm{~m}( \pm 100 \mathrm{~m}$ from the sampling locations). Because research cruises are often planned to observe sporadic, small-scale events, excluding data by specifying a large spatial scale is reasonable when comparing observed dissolved iron data with simulated results. Skill scores based on a comparison of the simulated results with all the field data and data excluding the subsets are summarized in Table 2. This data screening removed 4546 out of 8238 observations in surface water $(0-200 \mathrm{~m})$ and 2463 out of 3788 observations in deep water $(200-5000 \mathrm{~m})$. Although the skill scores were improved by this screening, the skill score of the AOU 06 case, which produced the best skill score among the $\mathrm{AOU}^{-}$series, was always higher than the skill score of the CONST 06 case, which produced the best skill score among the CONST series, the implication being that our main conclusions were not a result of this screening procedure.

\section{Results}

[24] We first describe results for five characteristic cases: CONST 00, CONST 06, CONST 12, AOU 06, and

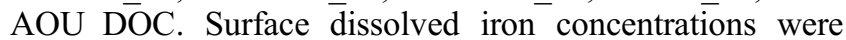
simulated reasonably well in all of these cases (Figures 2 and 3). The concentrations in the iron-limited areas, the Southern Ocean and the equatorial and subarctic North Pacific, were less than $0.3 \mathrm{nM}$ in the open ocean in all of these cases, a result that is consistent with field data. The insensitivity of the results in the iron-limited areas to differences in ligand concentrations reflects the fact that biological uptake buffers changes in iron concentrations. Even in the case without ligands (CONST_00), the model overestimated the surface iron concentrations in the Atlantic and Indian oceans, where dust depositions are large (Figure 3a). The overestimations became more prominent as $\left\langle L_{2}\right\rangle$ increased (Figures $3 \mathrm{a}-3 \mathrm{c}$ ). The model greatly underestimated surface iron concentrations in the Arctic Ocean in all cases.

[25] In deep waters we found larger differences among the cases (Figures 4 and 5). The CONST 00 case underestimated the iron concentrations, especially in the Pacific (Figures 4a and 5a), whereas the CONST_12 case markedly overestimated iron concentrations in the Atlantic (Figures $4 \mathrm{c}$ and 5c). Compared to these two extreme cases, the CONST_06 case simulated deep-water iron concentrations reasonably well, though the concentrations in the Atlantic (Pacific) were overestimated (underestimated) (Figures $4 \mathrm{~b}$ and 5b). The AOU_06 case produced lower (higher) concentrations in the Atlantic (Pacific) than did the CONST_06 case, the result being better skill scores for the AOU_06 case (the coefficient of determination, $R=0.61$; and the root mean square error, $\mathrm{RMSE}=0.23 \mathrm{nM}$ ) than for the CONST 06 case $\left(R^{2}=0.46\right.$, and RMSE $\left.=0.27 \mathrm{nM}\right)$. Use of the DOC-based ligand distribution in surface water (AOU_DOC case) hardly changed the simulated deep-water dissolved iron concentrations compared to the AOU 06 case (Figures 4d, 4e, 5d, and 5e).

[26] We next describe results for all the cases, with a focus on the sensitivity of the skill scores to the parameters (Figure 6). The surface water $R^{2}$ values were insensitive $\left(0-200 \mathrm{~m} ; R^{2}=0.30-0.37\right)$ to choices of $\left\langle L_{2}>, f\right.$, and the ligand formulations (Figures 6a-6d). This insensitivity reflects the fact that external iron inputs and biological uptake primarily determine the large-scale distribution of iron in surface waters. In the CONST series, the surface water RMSEs increased monotonically with increasing $\left.<L_{2}\right\rangle$ (Figure 6e). The increase of the RMSE was driven by the elevated surface water iron concentrations in the 
Atlantic and Indian Oceans (Figures 3a-3c). Because the surface water $\mathrm{L}_{2}$ concentrations remained low in the AOU series (Figure 1b), the surface water RMSEs were similar to those in the CONST_00 and CONST_02 cases (Figures 6e and $6 \mathrm{f}$ ). High surface water ligand concentrations in the AOU_DOC case (Figure 1c) and elevated surface water iron concentrations in the Atlantic and Indian Oceans (Figure 3e) resulted in a large surface water RMSE (Figure 6h). The surface water $R^{2}$ and RMSE in the AOU_MDL case were similar to those in the AOU_06 case.

[27] Results for the deep water $(200-5000 \mathrm{~m})$ showed a maximum $R^{2}$ and a minimum RMSE for $\left\langle L_{2}\right\rangle=0.6-0.8 \mathrm{nM}$ for both the CONST and the AOU series (Figures 6a, 6b, 6e, and $6 \mathrm{f}$ ). A comparison of cases with the same $\left\langle L_{2}>\right.$ revealed that the skill scores in the AOU series were always better than those in the CONST series. Decreasing $f$ and increasing the contribution from the AOU term improved both skill scores (Figures $6 \mathrm{c}$ and $6 \mathrm{~g}$ ). Simulated deep-water iron concentrations for the AOU_MDL and AOU_DOC cases were comparable to those in the AOU_06 case (Figures 6d and 6h).

\section{Discussion}

\subsection{Plausible $L_{2}$ Ligand Concentrations and Distributions}

[28] Because $\mathrm{L}_{2}$ ligands primarily control dissolved iron concentrations, results for deep waters $(200-5000 \mathrm{~m})$ are a good metric for investigating the distribution of $\mathrm{L}_{2}$ ligands. Both the CONST and AOU series show the highest $R^{2}$ and the lowest RMSE for $\left\langle L_{2}\right\rangle=0.6-0.8 \mathrm{nM}$ in deep water, the implication being that $0.6-0.8 \mathrm{nM}$ is a plausible range of concentrations for $\mathrm{L}_{2}$ ligands. The optimal $\mathrm{L}_{2}$ concentration in the model is within $1 \sigma$ of observed deep-water ligand concentrations measured by competitive ligand equilibration, adsorptive cathodic stripping voltammetry (CLE/ ACSV) (Table 3). However, use of the average ligand concentration in the observed data (e.g., the global average of $1.17 \mathrm{nM}$ (Table 3)) as the $\left\langle L_{2}\right\rangle$ parameter in the model overestimates simulated dissolved iron concentrations (e.g., the CONST_12 and AOU_12 cases).

[29] The fact that the optimal $\overline{\mathrm{L}}_{2}$ ligand concentrations in the model were low compared to observations can be attributed to an underestimation of simulated iron removal rates, because lowering the ligand concentrations compensates for the underestimation. Many previous field studies have shown that a substantial fraction of dissolved iron in seawater actually exists as colloids [Wu et al., 2001; Nishioka et al., 2001; Nishioka et al., 2003; Cullen et al., 2006; Nishioka et al., 2007; Boye et al., 2010], and colloidal iron likely aggregates into larger particles and settles out from seawater. A recent mesocosm experiment has confirmed that formation of colloids and subsequent aggregation removes dissolved iron rapidly after dust addition to seawater [Ye et al., 2011]. Their model simulation suggests that models lacking an explicit aggregation removal mechanism need to use high iron-removal rate constants to represent the combined effects of direct scavenging and colloidal aggregation. Because our model does not explicitly consider aggregation removal, it may underestimate the rate of iron removal, the result being a systematically low optimal $\mathrm{L}_{2}$ ligand concentration.

[30] Another possible explanation for the low optimal $\mathrm{L}_{2}$ concentration is competitive reactions between $\mathrm{L}_{2}$ ligands
Table 3. Basin-Averaged and Globally Averaged Ligand Concentrations and Standard Deviations in Deep Waters (Below $500 \mathrm{~m}$ ) Measured by CLE/ACSV

\begin{tabular}{lc}
\hline \multicolumn{1}{c}{ Basin } & Ligand Concentration $(\mathrm{nM})$ \\
\hline Atlantic $^{\mathrm{a}}$ & $1.25 \pm 0.65(n=34)$ \\
Southern Ocean $^{\mathrm{b}}$ & $1.03 \pm 0.51(n=118)$ \\
Pacific $^{\mathrm{c}}$ & $1.03 \pm 0.58(n=43)$ \\
Global & $1.17 \pm 0.58(n=195)$ \\
\hline
\end{tabular}

${ }^{\mathrm{a}}$ Boye et al. [2006], Cullen et al. [2006], and Thuróczy et al. [2010].

${ }^{\mathrm{b}}$ Boye et al. [2001], Croot et al. [2004], Gerringa et al. [2008], Boye et al. [2010], Ibisanmi et al. [2011], Thuróczy et al. [2011], and Kondo et al. [2012].

${ }^{\mathrm{c}}$ Rue and Bruland [1995], Kondo et al. [2007], and Kondo et al. [2012].

and transition metals. In coordination chemistry, constructing an organic ligand that binds nonspecifically to transition metals is much easier than constructing a ligand that binds to a particular metal [Hunter and Boyd, 2007]. In fact, Hirose and Tanoue [1994] suggested that binding of organic ligands to metal ions in seawater is nonspecific. Copper is considered to be bound by a large fraction of organic ligands [Hirose and Tanoue, 1994] and is the greatest competitor with iron for ligand acquisition. Simulated competitive reactions among organic ligands, iron, and copper have shown that iron can acquire only $0.1-0.4 \mathrm{nM}(10-40 \%)$ of a $1 \mathrm{nM}$ concentration of bulk organic ligands [Hirose, 2007] if the total copper concentration in seawater is 0.5-5 nM [Nozaki, 2001]. Because our model does not consider the copper cycle and competitive reactions, we may need to subtract a copper-bound fraction from the total ligand concentrations observed by CLE/ACSV to compare them with the model ligand concentrations.

[31] The large standard deviations observed in the field data (Table 3 ) can be partly attributed to analytical difference among studies. Expanding ligand intercalibration exercises to ensure comparability will decrease the standard deviations and provide better constraints for FeGCMs.

[32] The fact that hypothesizing $\mathrm{L}_{2}$ ligand concentrations to be a linear function of AOUs greatly improved simulated dissolved iron concentrations is consistent with the hypothesis, the implication being that $\mathrm{L}_{2}$ ligand concentrations should increase from the North Atlantic to the North Pacific. A possible explanation that accounts for the basin-scale gradients is that $\mathrm{L}_{2}$ ligands are a biologically refractory fraction of the DOC that is produced by bacterial degradation of sinking organic matter. The $\mathrm{L}_{2}$ ligands then accumulate in deep ocean water as it circulates along the pathways of deep-water circulation [Broecker and Peng, 1982]. In addition, our results have shown better model skill with lower $f$ values. The second term on the RHS of equation (4), $\left.f<L_{2}\right\rangle$, is the $\mathrm{L}_{2}$ ligand concentration when AOU equals zero, i.e., the concentration in surface waters. The fact that optimal $f$ values are low probably reflects photodegradation of $\mathrm{L}_{2}$ ligands in sunlit surface waters. The processes controlling $\mathrm{L}_{2}$ ligand and AOU are likely different in surface waters because air-sea exchange controls AOU. The situation is different in deep waters where remineralization controls both variables. To adequately represent the difference in surface waters, we will need to formulate $\mathrm{L}_{2}$ ligand as a prognostic variable independent from AOU.

[33] Our model simulations do not provide any information about the chemical composition of $\mathrm{L}_{2}$ ligands. However, 

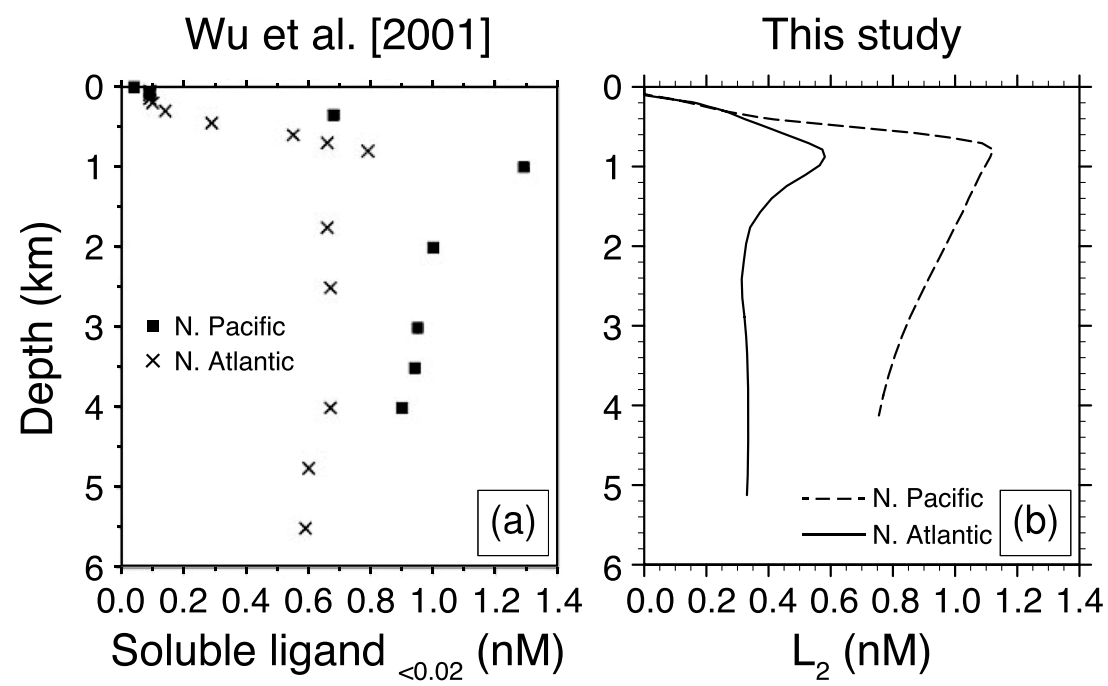

Figure 7. Vertical profiles of (a) soluble ligand concentrations $(<0.02 \mu \mathrm{m})$ measured by Wu et al. [2001] and the (b) $\mathrm{L}_{2}$ ligand concentrations used in the AOU 06 case. Squares and crosses in Figure 7a represent the data in the eastern North Atlantic $\left(22.8^{\circ} \mathrm{N}, 36.8^{\circ} \mathrm{W}\right)$ and the North Pacific near Hawaii $\left(23.8^{\circ} \mathrm{N}\right.$, $158.8^{\circ} \mathrm{W}$ ), respectively. Solid and dotted lines in Figure $7 \mathrm{~b}$ are the data from the same locations as Figure 7a for the Atlantic and the Pacific, respectively.

the linear relationship between $\mathrm{H}$-flu intensity and AOU [Yamashita and Tanoue, 2008], the iron-binding capacity of humic substances [Liu and Millero, 1999; Laglera and van den Berg, 2009], and observed significant correlations between $\mathrm{H}-$ flu intensity and iron solubility [Tani et al., 2003; Takata et al., 2005; Kitayama et al., 2009; Nishimura et al., 2012] all make humic substances strong candidates for $\mathrm{L}_{2}$ ligands.

[34] The observed ligand concentrations show only small basin-scale gradients (Table 3 ). It is possible ,however, that analytical inconsistencies associated with reported ligand concentrations conceal basin-scale gradients. In fact, soluble ligand concentrations in the North Atlantic and North Pacific determined with the same methodology [Wu et al., 2001] have revealed higher ligand concentrations in the North Pacific than in the North Atlantic, the vertical profiles being similar to those of the $\mathrm{L}_{2}$ ligand concentrations in the AOU_06 case (Figure 7). Note that Wu et al. [2001] actually measured the soluble fraction of $[\mathrm{FeL}]$ rather than the total ligand concentration usually measured by CLE/ACSV. More recently, Kondo et al. [2012] reported the latitudinal distribution of iron-binding ligands throughout the Pacific and the Southern Ocean by using CLE/ACSV and showed that the ligand distribution in deep waters is roughly similar to the distribution of the $\mathrm{H}$-flu intensity of CDOM and AOU measured by Yamashita and Tanoue [2008]. Thus, the large-scale ligand distributions in deep waters determined with the same methodology are consistent with our hypothesis. Ensuring the comparability of reported ligand concentrations is essential to further test the hypothesis.

[35] Our results do not provide constraints on the surface $\mathrm{L}_{2}$ ligand distribution. The surface $R^{2}$ values are insensitive to choices of $\left\langle L_{2}\right\rangle$ and $f$; the monotonic RMSE increase with increasing $\left\langle L_{2}\right\rangle$ seems problematic, because it is driven by the elevated surface iron concentrations in the Atlantic and Indian Oceans, where the model overestimates the concentrations, even for the case without ligands. The overestimation of surface dissolved iron can be partly attributed to overestimation of the fraction of dust that dissolves at sea surface assumed in the model (1\%). Mahowald et al. [2009] indicated that the fraction of aerosols from desert dust is thought to be $0.4 \%$ that is less than half of the fraction assumed in this study. Because the estimated fractions vary widely (0.01-80\%) [Mahowald et al., 2009 and references therein], reducing the uncertainty is essential to better simulate surface dissolved iron concentrations. Because multiple processes other than iron scavenging control surface water dissolved iron concentrations, we will need to evaluate the distribution of ligands in surface waters by considering various uncertainties.

[36] Adding the DOC-based surface ligand concentration (equation (6)) to the AOU-based ligand concentration (equation (4)) (i.e., the AOU_DOC case) greatly increases the surface RMSE. However, because of the model bias in surface waters, we cannot exclude the possibility of such a distribution of ligands. It is important to note, however, that the simulated deep-water dissolved iron concentrations hardly change between the AOU_06 and AOU_DOC cases, the implication being that the simulated deep-water dissolved iron concentrations are almost independent of the ligand distribution in the surface water. Thus, our conclusions with respect to the deep water $L_{2}$ distribution are robust, despite the model bias in surface waters.

[37] The results of the AOU_MDL and AOU_06 cases are similar, indicating that the influences of the bias in the simulated AOU and the interaction between iron and the binding ligands are small. It is, however, important to note that the interaction can lead to positive feedback in a future climate change scenario. Intensified stratification of surface waters can increase ligand concentrations in underlying waters by reducing photodegradation of ligands. The elevated ligand availability in subsurface waters will increase the supply of iron to surface waters from below, 


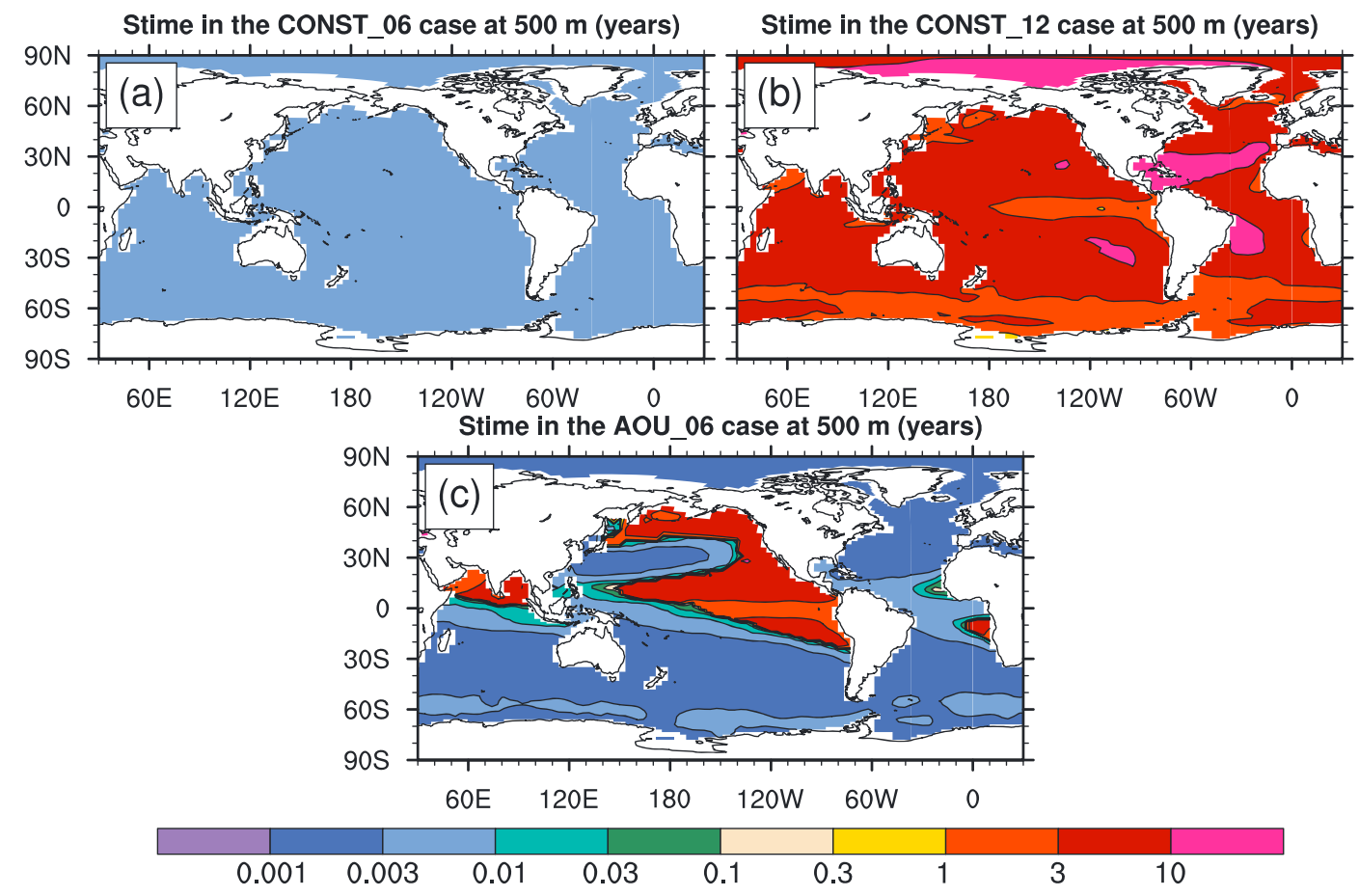

Figure 8. Spatial maps of the iron-scavenging timescale $S_{\text {time }}$ (years; see text for the definition) for a dissolved iron concentration of $0.9 \mathrm{nM}$ at a depth of $500 \mathrm{~m}$ for the (a) CONST_06, (b) CONST_12, and (c) AOU_06 cases.

the result being higher productivity in surface waters and more ligand production in subsurface waters. The importance of this positive feedback needs to be evaluated in future work.

\subsection{Mechanism to Improve Simulated Dissolved Iron Distributions}

[38] Misumi et al. [2011] introduced the iron-scavenging time scale $\left(S_{\text {time }}\right)$ defined as

$$
S_{\text {time }} \equiv-\frac{d F e}{s c a v}
$$

where $\mathrm{dFe}$ is the total dissolved iron concentration and $s c a v$ is the rate of change of $d F e$ due to iron scavenging. $S_{\text {time }}$ equals the residence time of dissolved iron if scavenging is the sole iron removal process. Here we calculate $S_{\text {time }}$ values for a typical high iron concentration of $0.9 \mathrm{nM}\left(S_{\text {time }}^{0.9}\right)$ at a depth of $500 \mathrm{~m}$. In the CONST_06 case, the model $S_{\text {time }}^{0.9}$ values are short (Figure $8 \mathrm{a})$, on the order of days $\left(S_{\text {time }}^{0.9}<0.01\right.$ year) in the global simulation. Because this short residence time prohibits advection of high iron concentrations from source areas, high concentrations $(>0.9 \mathrm{nM})$ are observed only in areas directly influenced by large external iron fluxes (Figure 4b): the equatorial Atlantic and the Indian Ocean from aeolian dust and coastal areas from seafloor sediments. In contrast, the $S_{\text {time }}^{0.9}$ values in the CONST_12 case (Figure 8b) are long, on the order of years, in the global simulation. The long $S_{\text {time }}^{0.9}$ values allow high iron concentrations to advect far from source areas, the result being improved simulation of iron distributions in the North Pacific (Figures 4c and 5c) because of the importance of horizontal advection of sedimentary iron to the open ocean [Johnson et al., 1997; Lam et al., 2006; Nishioka et al., 2007; Moore and Braucher, 2008; Misumi et al., 2011]. However, the long $S_{\text {time values in the North }}^{0.9}$ Atlantic result in excess northward transport of high iron concentrations by the Gulf Stream and North Atlantic Current, the result being considerable overestimation of iron concentrations in the North Atlantic (Figures 4c and 5c).

[39] Moderate concentrations of iron $(\sim 0.5 \mathrm{nM})$ observed in the midlatitudes of the North Atlantic (Figure 4f), despite its being located downstream of the equatorial Atlantic, a large dust deposition area, indicate that the $S_{\text {time }}$ values for high concentrations must be short in the North Atlantic. If we assume an advection speed of $5 \mathrm{~cm} \mathrm{~s}^{-1}$ and spatial scales for an anomaly of high iron concentrations advected from source areas of less than $500 \mathrm{~km}$, then the $S_{\text {time }}$ values for high concentrations must be shorter than 0.3 year in the North Atlantic. That scavenging time is an order of magnitude shorter than in the North Pacific, where the scavenging time is on the order of years [Misumi et al., 2011]. Such a large $S_{\text {time }}$ difference between the North Atlantic and North Pacific is difficult to reconcile with the homogeneous distribution of ligands. The assumption that the $\mathrm{L}_{2}$ ligand concentrations are proportional to AOUs leads to reasonable basin-scale gradients in $S_{\text {time }}$ at high iron concentrations (Figure 8c), the result being better simulated dissolved iron concentrations (Figure 4d).

[40] Basin-scale biases still remain in the simulated dissolved iron distributions in case AOU_06 (Figures 4d and 5d). The overestimation in the Southern Ocean may be attributable to overestimation of the rate of dust deposition in this study [Luo et al., 2003]. Wagener et al. [2008b] noted that the dust deposition estimates calculated by Luo et al. [2003] are up to 2 orders of magnitudes higher than in situ measurements in Southern Hemisphere oceans. Relatively poor representation of the spatial pattern of dissolved iron in the deep waters of the Southern Ocean (Table $2 ; R^{2}=0.26$, for $200-5000 \mathrm{~m}$ ) may also be 
attributed in part to lack of iron inputs from hydrothermal activity in our model [Tagliabue et al., 2010]. The large underestimation in the surface Arctic Ocean is possibly attributed to lack of riverine input of both dissolved iron and organic ligands in our simulation. Recent studies suggested that surface Arctic Ocean waters are strongly influenced by lateral transport of riverine dissolved iron and humic-type CDOM [Nakayama et al., 2011; Nishimura et al., 2012; Klunder et al., 2012]. Too much phytoplankton growth and biological drawdown of dissolved iron in the Arctic Ocean due to insufficient light limitation in the model (Moore et al., submitted manuscript) also likely contribute to the underestimation. In the North Atlantic, the AOU_06 case simulates iron concentrations very well at depths of $20 \overline{0}-1000 \mathrm{~m}\left(R^{2}=0.71\right)$, but the model shows poor skill at depths of $1000-5000 \mathrm{~m}\left(R^{2}=0.25\right)$ and generally underestimates the concentrations. This underestimation reflects simulated ligand concentrations that are too low in the deep waters of the Atlantic in the AOU 06 case (i.e., the locations "A" and "B" in Figure 1). Nelson et al. [2007] showed that CDOM concentrations are almost homogeneous below $1000 \mathrm{~m}$ in the Atlantic, and there is no statistically significant correlation between CDOM and AOU in the deep Atlantic. Thus, if humic-type CDOM concentrations can be used as a direct proxy for concentrations of $\mathrm{L}_{2}$ ligands, simulated dissolved iron concentrations will likely be further improved in the North Atlantic.

\section{Conclusion}

[41] We have investigated the simulated distribution of weak iron-binding ligands ( $\mathrm{L}_{2}$ ligands) by using the biogeochemical elemental cycling model, a global 3-D ocean simulation. We used an objectively analyzed, data-based AOU distribution as a proxy for $\mathrm{L}_{2}$ ligand concentrations based on previously published observational studies. We found that introducing the AOU-based $\mathrm{L}_{2}$ ligand distribution led to iron residence times that were more than an order of magnitude shorter at high iron concentrations in the North Atlantic (on the order of days) than in the North Pacific (on the order of years), leading to a substantial improvement in the simulated dissolved iron distribution compared to simulations with homogeneous ligand concentrations. The basin-scale $\mathrm{L}_{2}$ ligand gradients are consistent with the assumption that $\mathrm{L}_{2}$ ligands are a biologically refractory fraction of DOC produced by bacterial degradation of sinking organic matter and are subjected to photodegradation in sunlit surface waters. In conjunction with previous observational evidence, our model results suggest that humic substances probably account for a large fraction of $\mathrm{L}_{2}$ ligands. Ensuring comparability of reported ligand concentrations, incorporating into models the effects of colloidal aggregation, the copper cycle, and competitive reactions among $\mathrm{L}_{1}$ ligands, $\mathrm{L}_{2}$ ligands, iron, and copper, and investigating global distributions of humic-type CDOM can further improve iron cycle models.

[42] Acknowledgments. We thank F. O. Bryan for his scientific support and input to this project. We acknowledge A. Tagliabue for providing the compiled dissolved iron data. This paper has also benefited from insightful comments from K. Hirose, K. Kuma, Y. Yamashita, J. Nishioka, T. Yoshimura, K. Sugie, and two anonymous reviewers. S. C. Doney acknowledges support from the U.S. National Science Foundation (EF0424599). This work was also supported by NSF grant OCE-0928204 to J. K. Moore. The National Center for Atmospheric Research is sponsored by the National Science Foundation.

\section{References}

Aumont, O., and L. Bopp (2006), Globalizing results from ocean in situ iron fertilization studies, Global Biogeochem. Cycles, 20, GB2017, doi:10.1029/2005GB002591.

van den Berg, C. M. G. (1995), Evidence for organic complexation of iron in seawater, Mar. Chem., 50, 139-157.

Boyd, P. W., and M. J. Ellwood (2010), The biogeochemical cycle of iron in the ocean, Nat. Geosci., 3, 675-682, doi:10.1038/ngeo964.

Boyd, P. W., E. Ibisanmi, S. G. Sander, K. A. Hunter, and G. A. Jackson (2010), Remineralization of upper ocean particles: Implications for iron biogeochemistry, Limnol. Oceanog., 55, 1271-1288, doi:10.4319/lo.2010.55.3.1271.

Boye, M., C. M. G. van den Berg, J. T. M. de Jong, H. Leach, P. Croot, and H. J. W. de Baar (2001), Organic complexation of iron in the Southern Ocean, Deep Sea Res. Part I: Oceanogr. Res. Papers, 48(6), 1477-1497, doi:10.1016/S0967-0637(00)00099-6.

Boye, M., A. Aldrich, C. M. G. van den Berg, J. T. M. de Jong, H. Nirmaier, M. Veldhuis, K. R. Timmermans, and H. J. W. de Baar (2006), The chemical speciation of iron in the north-east Atlantic Ocean, Deep Sea Res. Part I, 53, 667-683, doi:10.1016/j.dsr.2005.12.015.

Boye, M., J. Nishioka, P. Croot, P. Laan, K. R. Timmermans, V. H. Strass, S. Takeda, and H. J. W. de Baar (2010), Significant portion of dissolved organic Fe complexes in fact is Fe colloids, Mar. Chem., 122, 20-27, doi:10.1016/j.marchem.2010.09.001.

Broecker, W. S., and T.-H. Peng (1982), Tracers in the Sea, 690 pp. Lamont-Doherty Geological Observatory, Palisades, New York.

Conkright, M. E., et al. (1998), World Ocean Atlas Database 1998 CDROM data set documentation, Silver Spring, MD.

Croot, P. L., K. Andersson, M. Öztürk, and D. R. Turner (2004), The distribution and speciation of iron along $6^{\circ} \mathrm{E}$ in the Southern Ocean, Deep Sea Res. Part II, 51, 2857-2879, doi:10.1016/j.dsr2.2003.10.012.

Cullen, J. T., B. A. Bergquist, and J. W. Moffett (2006), Thermodynamic characterization of the partitioning of iron between soluble and colloidal species in the Atlantic Ocean, Mar. Chem., 98, 295-303, doi:10.1016/ j.marchem.2005.10.007.

Danabasoglu, G., S. C. Bates, B. P. Briegleb, S. R. Jayne, M. Jochum, W. G. Large, S. Peacock, and S. G. Yeager (2012), The CCSM4 Ocean Component, J. Clim., 25, 1361-1389, doi:10.1175/JCLI-D-11-00091.1.

Doney, S. C., K. Lindsay, I. Fung, and J. John (2006), Natural variability in a stable, 1000-yr global coupled climate-carbon cycle simulation, J. Clim., 19, 3033-3054.

Doney, S. C., I. Lima, R. A. Feely, D. M. Glover, K. Lindsay, N. Mahowald, J. K. Moore, and R. Wanninkhof (2009a), Mechanisms governing interannual variability in upper-ocean inorganic carbon system and air-sea $\mathrm{CO}_{2}$ fluxes: Physical climate and atmospheric dust, Deep Sea Res. Part II, 56, 640-655, doi:10.1016/j.dsr2.2008.12.006.

Doney, S. C., I. Lima, J. K. Moore, K. Lindsay, M. J. Behrenfeld, T. K. Westberry, N. Mahowald, D. M. Glover, and T. Takahashi (2009b), Skill metrics for confronting global upper ocean ecosystembiogeochemistry models against field and remote sensing data, J. Mar. Sys., 76, 95-112, doi:10.1016/j.jmarsys.2008.05.015.

Garcia, H. E., R. A. Locarnini, T. P. Boyer, J. I. Antonov, O. K. Baranova, M. M. Zweng, and D. R. Johnson (2010), Dissolved Oxygen, Apparent Oxygen Utilization, and Oxygen Saturation, 344 pp., U. S. Government Printing Office, Washington, D. C.

Gerringa, L. J. A., S. Blain, P. Laan, G. Sarthou, M. J. W. Veldhuis, C. P. D. Brussaard, E. Viollier, and K. R. Timmermans (2008), Fe-binding dissolved organic ligands near the Kerguelen Archipelago in the Southern Ocean (Indian sector), Deep Sea Res. Part II, 55, 606-621, doi:10.1016/j.dsr2.2007.12.007.

Gledhill, M., and C. M. G. van den Berg (1994), Determination of complexation of iron(III) with natural organic complexing ligands in seawater using cathodic stripping voltammetry, Mar. Chem., 47, 41-54, doi:10.1016/0304-4203(94)90012-4.

Hirose, K. (2007), Metal-organic matter interaction: Ecological roles of ligands in oceanic DOM, Appl. Geochem., 22, 1636-1645, doi:10.1016/ j.apgeochem.2007.03.042.

Hirose, K., and E. Tanoue (1994), Thorium-particulate matter interaction. Thorium complexing capacity of oceanic particulate matter: Theory, Geochim. Cosmochim. Acta, 58, 1-7.

Holland, M. M., D. A. Bailey, B. P. Briegleb, B. Light, and E. Hunke (2012), Improved sea ice shortwave radiation physics in CCSM4: The impact of melt ponds and aerosols on Arctic sea ice, J. Clim., 25(5), 1413-1430, doi:10.1175/JCLI-D-11-00078.1.

Huffman, G. J., R. F. Adler, P. Arkin, A. Chang, R. Ferraro, A. Gruber, J. Janowiak, A. Mcnab, B. Rudolf, and U. Schneider (1997), The global precipitation climatology project (GPCP) combined precipitation dataset, Bull. Am. Meteor. Soc., 78, 5-20.

Hunke, E. C., and W. H. Lipscomb (2008), CICE: The Los Alamos sea ice model user's manual, version 4. 
Hunter, K. A., and P. W. Boyd (2007), Iron-binding ligands and their role in the ocean biogeochemistry of iron, Environ. Chem., 4, 221-232, doi:10.1071/EN07012.

Ibisanmi, E., S. G. Sander, P. W. Boyd, A. R. Bowie, and K. A. Hunter (2011), Vertical distributions of iron-(III) complexing ligands in the Southern Ocean, Deep Sea Res. Part II, 58, 2113-2125, doi:10.1016/j.dsr2.2011.05.028.

Johnson, K. S., R. M. Gordon, and K. H. Coale (1997), What controls dissolved iron concentrations in the world ocean?, Mar. Chem., 57, 137-161, doi:10.1016/S0304-4203(97)00043-1.

Kalnay, E., et al. (1996), The NCEP/NCAR 40-year reanalysis project, Bull. Am. Meteor. Soc., 77, 437-471.

Key, R. M., A. Kozyr, C. L. Sabine, K. Lee, R. Wanninkhof, J. L. Bullister, R. A. Feely, F. J. Millero, C. Mordy, and T.-H. Peng (2004), A globa ocean carbon climatology: Results from Global Data Analysis Project (GLODAP), Global Biogeochem. Cycles, 18, GB4031, doi:10.1029/ 2004GB002247.

Kitayama, S., et al. (2009), Controls on iron distributions in the deep water column of the North Pacific Ocean: Iron(III) hydroxide solubility and marine humic-type dissolved organic matter, J. Geophys. Res., 114 , C08019, doi:10.1029/2008JC004754.

Klunder, M. B., D. Bauch, P. Laan, H. J. W. de Baar, S. van Heuven, and S. Ober (2012), Dissolved iron in the Arctic shelf seas and surface waters of the central Arctic Ocean: Impact of Arctic river water and ice-melt J. Geophys. Res., 117(C1), C01027, doi:10.1029/2011JC007133.

Kondo, Y., S. Takeda, and K. Furuya (2007), Distribution and speciation of dissolved iron in the Sulu Sea and its adjacent waters, Deep Sea Res. Part II, 54, 60-80, doi:10.1016/j.dsr2.2006.08.019.

Kondo, Y., S. Takeda, and K. Furuya (2012), Distinct trends in dissolved Fe speciation between shallow and deep waters in the Pacific Ocean, Mar. Chem., 134-135, 18-28, doi:10.1016/j.marchem.2012.03.002.

Laglera, L. M., and C. M. G. van den Berg (2009), Evidence for geochemical control of iron by humic substances in seawater, Limnol. Oceanogr. 54, 610-619, doi:10.4319/1o.2009.54.2.0610.

Lam, P. J., J. K. B. Bishop, C. C. Henning, M. A. Marcus, G. A. Waychunas, and I. Y. Fung (2006), Wintertime phytoplankton bloom in the subarctic Pacific supported by continental margin iron, Global Biogeochem. Cycles, 20, GB1006, doi:10.1029/2005GB002557.

Large, W. G., and S. G. Yeager (2004), Diurnal to decadal global forcing for ocean and sea-ice models: The data sets and flux climatologies, Boulder, CO.

Liu, X., and F. J. Millero (1999), The solubility of iron hydroxide in sodium chloride solutions, Geochim. Cosmochim. Acta, 63, 3487-3497.

Luo, C., M. Mahowald, and J. del Corral (2003), Sensitivity study of meteorological parameters on mineral aerosol mobilization, transport, and distribution, J. Geophys. Res., 108(D5), doi:10.1029/2003JD003483.

Macrellis, H. M., C. G. Trick, E. L. Rue, G. Smith, and K. W. Bruland (2001), Collection and detection of natural iron-binding ligands from seawater, Mar. Chem., 76, 175-187, doi:10.1016/S0304-4203(01)00061-5.

Mahowald, N. M., et al. (2009), Atmospheric iron deposition: global distribution, variability, and human perturbations, Annu. Rev. Mar. Sci., 1, 245-278, doi:10.1146/annurev.marine.010908.163727.

Mawji, E., M. Gledhill, J. A. Milton, G. A. Tarran, S. Ussher, A. Thompson, G. A. Wolff, P. J. Worsfold, and E. P. Achterberg (2008), Hydroxamate siderophores: Occurrence and importance in the Atlantic Ocean, Environ. Sci. Technol., 42, 8675-8680, doi:10.1021/es801884r.

Misumi, K., et al. (2011), Mechanisms controlling dissolved iron distribution in the North Pacific: A model study, J. Geophys. Res., 116, G03005, doi:10.1029/2010JG001541.

Moore, J. K., and O. Braucher (2008), Sedimentary and mineral dust sources of dissolved iron to the world ocean, Biogeosci., 5, 631-656.

Moore, J. K., S. C. Doney, and K. Lindsay (2004), Upper ocean ecosystem dynamics and iron cycling in a global three-dimensional model, Global Biogeochem. Cycles, 18, GB4028, doi:10.1029/2004GB002220.

Nakayama, Y., S. Fujita, K. Kuma, and K. Shimada (2011), Iron and humictype fluorescent dissolved organic matter in the Chukchi Sea and Canada Basin of the western Arctic Ocean, J. Geophys. Res., 116, C07031, doi:10.1029/2010JC006779.

Nelson, N. B., D. A. Siegel, C. A. Carlson, C. Swan, W. M. Smethie Jr, and S. Khatiwala (2007), Hydrography of chromophoric dissolved organic matter in the North Atlantic, Deep Sea Res. Part I, 54, 710-731, doi:10.1016/j.dsr.2007.02.006.

Nishimura, S., K. Kuma, S. Ishikawa, A. Omata, and S. Saitoh (2012), Iron, nutrients, and humic-type fluorescent dissolved organic matter in the northern Bering Sea shelf, Bering Strait, and Chukchi Sea, J. Geophys. Res., 117, C02025, doi:10.1029/2011JC007355.

Nishioka, J., S. Takeda, C. S. Wong, and W. K. Johnson (2001), Size-fractionated iron concentrations in the northeast Pacific Ocean: Distribution of soluble and small colloidal iron, Mar. Chem., 74, 157-179, doi:10.1016/S03044203(01)00013-5.

Nishioka, J., S. Takeda, I. Kudo, D. Tsumune, T. Yoshimura, K. Kuma, and A. Tsuda (2003), Size-fractionated iron distributions and iron-limitation processes in the subarctic NW Pacific, Geophys. Res. Lett., 30(14), doi:10.1029/2002GL016853.

Nishioka, J., et al. (2007), Iron supply to the western subarctic Pacific: Importance of iron export from the Sea of Okhotsk, J. Geophys. Res. 112, C10012, doi:10.1029/2006JC004055.

Nozaki, Y. (2001), Elemental distribution, in Encyclopedia of Ocean Sciences Vol. 2, edited by J. H. Steele, et al., pp. 840-845, Academic Press, London.

Parekh, P., M. J. Follows, and E. A. Boyle (2005), Decoupling of iron and phosphate in the global ocean, Global Biogeochem. Cycles, 19, GB2020 doi:10.1029/2004GB002280.

Poorvin, L., S. G. Sander, I. Velasquez, E. Ibisanmi, G. R. LeCleir, and S. W. Wilhelm (2011), A comparison of Fe bioavailability and binding of a catecholate siderophore with virus-mediated lysates from the marine bacterium Vibrio alginolyticus PWH3a, J. Exp. Mar. Biol. Ecol. 399, 43-47, doi:10.1016/j.jembe.2011.01.016.

Reid, R. T., D. H. Live, J. D. Faulkner, and A. Butler (1993), A siderophore from a marine bacterium with an exceptional ferric ion affinity constant Nature, 366, 455-458.

Rue, E. L., and K. W. Bruland (1995), Complexation of iron (III) by natural organic ligands in the Central North Pacific as determined by a new competitive ligand equilibration/adsorptive cathodic stripping voltammetric method, Mar. Chem., 50, 117-138.

Sato, M., S. Takeda, and K. Furuya (2007), Iron regeneration and organic iron (III)-binding ligand production during in situ zooplankton grazing experiment, Mar. Chem., 106, 471-488, doi:10.1016/j.marchem.2007.05.001.

Shields, C. A., D. A. Bailey, G. Danabasoglu, M. Jochum, J. T. Kiehl, S. Levis, and S. Park (2012), The low resolution CCSM4, J. Clim., 25, 3993-4014, doi:10.1175/JCLI-D-11-00260.1.

Smith, R., et al. (2010), The Parallel Ocean Program (POP) reference manual, Ocean component of the Community Climate System Model (CCSM) and Community Earth System Model (CESM).

Steele, M., R. Morley, and W. Ermold (2001), PHC: A global ocean hydrography with a high-quality Arctic Ocean, J. Clim., 14, 2079-2087.

Tagliabue, A., and C. Völker (2011), Towards accounting for dissolved iron speciation in global ocean models, Biogeosci., 8, 3025-3039, doi:10.5194 bg-8-3025-2011.

Tagliabue, A., et al. (2010), Hydrothermal contribution to the oceanic dissolved iron inventory, Nat. Geosci., 3, 252-256, doi:10.1038/ngeo818.

Tagliabue, A., T. Mtshali, O. Aumont, A. R. Bowie, M. B. Klunder, A. N. Roychoudhury, and S. Swart (2012), A global compilation of dissolved iron measurements: Focus on distributions and processes in the Southern Ocean, Biogeosci., 9, 2333-2349, doi:10.5194/bg-9-2333-2012.

Takata, H., K. Kuma, S. Iwade, Y. Isoda, H. Kuroda, and T. Senjyu (2005) Comparative vertical distributions of iron in the Japan Sea, the Bering Sea, and the western North Pacific Ocean, J. Geophys. Res., 110, C07004, doi:10.1029/2004JC002783.

Tani, H., J. Nishioka, K. Kuma, H. Takata, Y. Yamashita, E. Tanoue, and T. Midorikawa (2003), Iron(III) hydroxide solubility and humictype fluorescent organic matter in the deep water column of the Okhotsk Sea and the northwestern North Pacific Ocean, Deep Sea Res. Part I, 50, 1063-1078, doi:10.1016/S0967-0637(03)00098-0.

Thuróczy, C.-E., L. J. A. Gerringa, M. B. Klunder, R. Middag, P. Laan, K. R. Timmermans, and H. J. W. de Baar (2010), Speciation of Fe in the Eastern North Atlantic Ocean, Deep Sea Res. Part I, 57 , 1444-1453, doi:10.1016/j.dsr.2010.08.004.

Thuróczy, C.-E., L. J. A. Gerringa, M. B. Klunder, P. Laan, and H. J. W. de Baar (2011), Observation of consistent trends in the organic complexation of dissolved iron in the Atlantic sector of the Southern Ocean, Deep Sea Res. Part II, 58, 2695-2706, doi:10.1016 j.dsr2.2011.01.002

Wagener, T., E. Pulido-Villena, and C. Guieu (2008a), Dust iron dissolution in seawater: Results from a one-year time-series in the Mediterranean Sea, Geophys. Res. Lett., 35, L16601, doi:10.1029/ 2008GL034581.

Wagener, T., C. Guieu, R. Losno, S. Bonnet, and N. Mahowald (2008b), Revisiting atmospheric dust export to the Southern Hemisphere ocean Biogeochemical implications, Global Biogeochem. Cycles, 22, GB2006, doi:10.1029/2007GB002984.

Wu, J., E. Boyle, W. Sunda, and L.-S. Wen (2001), Soluble and colloidal iron in the oligotrophic North Atlantic and North Pacific, Science, 293 847-849, doi:10.1126/science.1059251.

Xie, P., and P. A. Arkin (1996), Analyses of global monthly precipitation using gauge observations, satellite estimates, and numerical model predictions, J. Clim., 9, 840-858.

Yamashita, Y., and E. Tanoue (2008), Production of bio-refractory fluorescent dissolved organic matter in the ocean interior, Nat. Geosci. 1, 579-582, doi:10.1038/ngeo279.

Ye, Y., C. Völker, and D. A. Wolf-Gladrow (2009), A model of Fe speciation and biogeochemistry at the Tropical Eastern North Atlantic Time-+Series Observatory site, Biogeosci., 6, 2041-2061, doi:10.5194/bg-6-2041-2009. 


\section{MISUMI ET AL.: LIGAND DISTRIBUTION IN THE GLOBAL OCEAN}

Ye, Y., T. Wagener, C. Völker, C. Guieu, and D. A. Wolf-Gladrow (2011), Dust deposition: Iron source or sink? A case study, Biogeosci., 8, 2107-2124, doi:10.5194/bg-8-2107-2011.

Yeager, S. G., and M. Jochum (2009), The connection between Labrador Sea buoyancy loss, deep western boundary current strength, and Gulf Stream path in an ocean circulation model, Ocean Model., 30, 207-224, doi:10.1016/j.ocemod.2009.06.014
Yeager, S. G., C. A. Shields, W. G. Large, and J. J. Hack (2006), The lowresolution CCSM3, J. Clim., 19, 2545-2566.

Zhang, Y., W. B. Rossow, A. A. Lacis, V. Oinas, and M. I. Mishchenko (2004), Calculation of radiative fluxes from the surface to top of atmosphere based on ISCCP and other global data sets: Refinements of the radiative transfer model and the input data, J. Geophys. Res., 109, D19105, doi:10.1029/2003JD004457. 